\title{
PENGEMBANGAN BAHAN AJAR MATERI PERSAMAAN KUADRAT BERBANTUAN RUMUS CEPAT
}

\author{
Nur Kesumayanti $^{(1)}$, Rizki Wahyu Yunian Putra ${ }^{(2)}$ \\ ${ }^{1) 2)}$ UIN Raden Intan Lampung, Jl. Letkol H. Endro Suratmin Sukarame - Bandar Lampung; \\ $\underline{\text { nurkesuma231216@gmail.com }}^{l)}$ rizkiputra8916@yahoo.com $^{2)}$
}

\begin{abstract}
The purpose of this research is to produce material of quadratic equations supported by quick, appealing, and easy formula for students. The Method of This research is Research and Development Procedure ( R \& D) from Brog and Gall which is adopted by Sucipto that is up to the seventh stage, such as: potential problem, data collection, product design, design validation, design revision, product trial, and product revisions. The subject of this research is one of high school students in Bandar Lampung. The data collection was obtained from the validation of the instruments as well as trials of small group and large group products. This researchs analyzed by descriptive quantitative and qualitative. The products produced through the validation of the feasibility of the material expert validator team, the media expert, the linguist and the mathematic teacher and the language teacher obtained the criteria "Very worthy of use". furthermore on the aspects of small group and large group product trial obtained the criteria "Very easy and very interesting for students". Based on the results of assessment of responses by experts, teachers, and student responses it can be concluded that the material module of quadratic equations aided by the formula is quickly categorized very feasible, very interesting, and very easy for students.

Keywords: Teaching Materials, Quadratic Equations, Quick Formulas.
\end{abstract}

\section{ABSTRAK}

Tujuan penelitian pengembangan bahan ajar materi persamaan kuadrat berbantun rumus cepat ini dilakukan untuk menghasilkan bahan ajar materi persamaan kuadrat berbantuan rumus cepat layak, menarik, dan mudah bagi siswa. Metode penelitian ini menggunakan prosedur pengembangan Reaserch and Development $(R \& D)$ dari Brog and Gall yang diadopsi oleh Sucipto yakni sampai pada tahap ke tujuh, diantaranya: potensi masalah, pengumpulan data, desain produk, validasi desain, revisi desain, uji coba produk, dan revisi produk. Subjek penelitian ini adalah siswa-siswi salah satu SMA di Bandar Lampung. Pengumpulan data diperoleh dari hasil validasi instrumen serta uji coba produk kelompok kecil dan kelompok besar. Instrumen yang dilakukan berupa skala penilaian. Kemudian dianalisis dengan deskriptif kuantitatif dan kualitatif. Produk yang dihasilkan melalui tahap validasi kelayakan bahan ajar kepada tim validator ahli materi, ahli media, ahli bahasa serta guru matematika dan guru bahasa memperoleh kriteria "Sangat layak digunakan". selanjutnya pada aspek uji coba produk kelompok kecil dan kelompok besar memperoleh kriteria "Sangat mudah 
dan sangat menarik bagi siswa". Berdasarkan hasil penilaian tanggapan oleh para ahli, guru, dan respon siswa maka dapat disimpulkan bahwa modul materi persamaan kuadrat berbantuan rumus cepat dikategorikan sangat layak, sangat menarik, dan sangat mudah bagi siswa.

Kata Kunci : Bahan Ajar, Persamaan Kuadrat, Rumus Cepat

\section{PENDAHULUAN}

Pendidikan merupakan suatu usaha yang mempersiapkan sumber daya manusia melalui kegiatan pembelajaran, bimbingan, dan latihan bagi peranannya di masa mendatang. Tujuan pendidikan nasional menurut UUD No. 20 Tahun 2003 pasal 3 berfungsi untuk berkembangnya potensi peserta didik agar menjadi manusia yang beriman dan bertaqwa kepada Tuhan Yang Maha Esa, berakhlak mulia, sehat, berilmu, cakap, kreatif, mandiri dan menjadi warga negara yang demokratis serta bertanggung jawab.

Belajar adalah suatu proses pribadi yang tidak harus atau merupakan akibat kegiatan pembelajaran. Menurut Andi prastowo, (2014:122) guru melakukan kegiatan pembelajaran tidak selalu diikuti terjadinya kegiatan belajar pada siswa. Sebaliknya, siswa dapat melakukan kegiatan belajar tanpa harus ada guru yang membelajarkan. Menurut wirasta yang dikutip Andi prastowo (2014:123) Belajar sesungguhnya (the real learning) perlu adanya sumber belajar. Sumber belajar adalah suatu sistem yang terdiri dari sekumpulan bahan atau situasi yang dikumpulkan secara sengaja dan dibuat agar memungkinkan siswa belajar secara individual. Menurut Daryanto
(2014:178) Modul merupakan satu paket kurikulum yang disediakan untuk belajar sendiri, karena modul adalah suatu unit yang berdiri sendiri dan terdiri atas suatu rangkaian kegiatan belajar yang disusun untuk membantu siswa mencapai sejumlah tujuan yang dirumuskan secara khusus dan jelas.

Persamaan kuadrat merupakan materi pembelajaran matematika tingkat SMA semester I, materi persamaan kuadrat sering dijumpai baik di ujian semester, ujian sekolah, ujian nasional maupun ujian masuk perguruan tinggi. Banyak sekali kesalahan-kesalahan yang dilakukan siswa saat ujian diselenggarakan, seperti halnya siswa yang tidak memahami konsep serta kurangnya dalam penguasaan berhitung, siswa akan merasa kesulitan untuk menjawab butir soal tersebut. Agar siswa dapat menguasai materi persamaan kuadrat dengan baik maka diperlukan pemahaman konsep serta kemampuan mengabtraksi dan bernalar yang cukup baik.

Berkaitan dengan hal ini untuk melihat kemampuan awal siswa di salah satu SMA di Bandar Lampung dalam menyelesaikan soal pre test, soal yang diberikan merupakan soal ujian nasional dan soal ujian masuk perguruan tinggi. Kemampuan siswa dalam menyelesaikan soal-soal 
persamaan kuadrat mempunyai banyak kendala. Hal ini dapat dilihat di tabel 1. dari hasil pre test siswa di salah satu SMA di Bandar Lampung kelas sebelas dengan waktu yang diberikan sebanyak 30 menit. Berikut beberapa soal yang mampu dijawab oleh siswa SMA kelas sebelas yakni:

Tabel 1.

Data Hasil Pre Test Siswa/i di salah satu SMA di Bandar Lampung Kelas Sebelas Sebanyak 16 Siswa Tahun 2016/2017

\begin{tabular}{|c|c|c|c|c|c|c|}
\hline No & $\begin{array}{c}\text { Nomor } \\
\text { Soal }\end{array}$ & Benar & Salah & $\%$ Benar & $\%$ Salah & Jumlah \% \\
\hline 1 & Soal 1 & 2 & 14 & $12,5 \%$ & $87,5 \%$ & \\
\hline 2 & Soal 2 & 1 & 15 & $6,25 \%$ & $93,75 \%$ & \\
\hline 3 & Soal 3 & 3 & 13 & $18,75 \%$ & $81,25 \%$ & \\
\hline 4 & Soal 4 & 3 & 13 & $18,75 \%$ & $81,25 \%$ & \\
\hline \multicolumn{4}{|c|}{ Jumlah rata-rata persentase } & $14,06 \%$ & $85,94 \%$ & $100 \%$ \\
\hline
\end{tabular}

Berdasarkan Tabel 1. di atas, dapat terlihat bahwa perbandingan siswa yang dapat mengerjakan soal tes dan yang tidak dapat mengerjakan soal tes sangatlah berbeda jauh perbandingannya. Dari hasil jumlah rata-rata persentase, siswa yang dapat mengerjakan soal tes persamaan kuadrat dengan benar rata-rata hanya $14.06 \%$ lebih kecil dari pada siswa yang tidak dapat mengerjakan soal tes persamaan kuadrat. Hasil rata-rata siswa yang mengerjakan soal tes persamaan kuadrat dengan jawaban salah adalah $85.94 \%$. sehingga dapat disimpulkan bahwa soal tes ujian nasional dan ujian masuk perguruan tinggi merupakan soal yang tergolong sulit. Pada soal nomor 3 dan 4 dapat dikerjakan melalui dua cara yakni cara normal dan cara cepat, jika dikerjakan menggunakan cara normal untuk menguraikan jawaban membutuhkan waktu yang cukup lama yakni berkisar 5-10 menit berbeda dengan menggunakan cara cepat waktu yang dibutuhkan relatif lebih singkat dan praktis yakni, kurang dari 2 menit bahkan beberapa detik saja dengan catatan mengetahui penggunaan rumus cepat. Oleh karena itu jelaslah selain soal yang tergolong sulit yakni siswa yang kurang dalam memanagement waktu dalam mengerjakan soal.

Selain hasil pre test, salah satu guru matematika SMA di Bandar Lampung mengaku bahwa siswa masih mengalami kesulitan dalam memahami konsep dasar matematika serta belum adanya pembahasan soalsoal ujian di dalam buku siswa. Hal ini menyebabkan kurangnya pengetahuan siswa dalam memahami pola-pola soal ujian yang diberikan.

Dari hasil penelitian inilah diduga bahwa upaya untuk meningkatkan hasil pembelajaran matematika pada siswa, yakni dengan cara perlu dikembangkannya modul yang materi di dalamnya berbentuk penguasaan konsep dasar materi yang terstruktur, menanamkan pemahaman pola soal, dan dapat menyelesaikan soal menggunakan rumus cepat dengan catatan mengetahui penggunaan rumus 
cepat, selain itu dengan adanya rumus cepat siswa dapat mengerjakan soal ujian dengan waktu yang tepat dan praktis. Rumus cepat dapat digunakan sebagai perbandingan hasil dalam penyelesaian menggunakan rumus biasa dan penyelesaian menggunakan rumus cepat, Rumus cepat tersebut dapat diaplikasikan dengan mudah dipahami oleh siswa dan dilakukan oleh guru maka dari itulah penggunaan rumus cepat dapat memupuk rasa percaya diri siswa dalam menyelesaikan soal-soal matematika dan mampu menghilangkan pandangan matematika yang sulit

\section{LANDASAN/KAJIAN TEORI}

Daryanto (2014: 171) Bahan ajar adalah seperangkat materi yang disusun secara sistematis baik tertulis maupun tidak sehingga tercipta lingkungan atau suasana yang memungkinkan siswa untuk belajar. Daryanto (2014:178) Modul merupakan suatu paket kurikulum yang disediakan untuk belajar sendiri, modul adalah suatu unit yang berdiri sendiri dan terdiri atas sutu rangkaian kegiatan belajar yang disusun untuk membantu siswa mencapai sejumlah tujuan yang dirumuskan secara khusus dan jelas.

Tujuan belajar digunakannya modul didalam proses belajar mengajar menurut B. Suryosubroto yang di kutip oleh Andi prastowo

(2014:183) ialah agar:

a. Tujuan pendidikan dapat dicapai secara efesien dan efektif.

b. Murid dapat mengikuti program pendidikan sesuai dengan kecepatan dan kemampuannya sendiri.

c. Murid dapat sebanyak mungkin menghayati dan melakukan kegiatan belajar sendiri, baik dibawah bimbingan atau tanpa bimbingan guru.

d. Murid dapat menilai dan mengetahui hasil belajarnya sendiri secara berkelanjutan.

e. Murid benar-benar menjadi titik pusat kegiatan belajar mengajar.

f. Kemajuan siswa dapat diikuti dengan frekuensi yang lebih tinggi melalui evaluasi yang dilakukan pada setiap mudul berakhir.

g. Modul disusun berdasar kepada konsep "Masterly Learning" suatu konsep yang menekankan bahwa murid harus secara optimal menguasai bahan pembelajaran yang disajikan dalam modul itu. Prinsip ini mengandung konsekuensi bahwa seorang murid tidak diperbolehkan mengikuti program berikutnya sebelum ia menguasai paling sedikit $75 \%$ dari bahan tersebut.

Rumus cepat merupakan bagian dari metode mathmagic, Irawan, (2016:88) metode mathmagic adalah metode pembelajaran matematika yang menitik beratkan pada pemahaman siswa akan konsep dasar matematika yang benar. prosedur penyelesaian matematika adalah suatu langkah-langkah dimana siswa secara bertahap akan bekerja dalam menguraikan tahap demi tahap sampai terselesainya soal matematika. Hal ini sesuai dengan pernyataan Setyono, (2005:8) menyatakan bahwa mahtmagic adalah suatu pendekatan dengan cara pandang baru terhadap 
matematika, terutama dalam cara penyampaian materi. Materi disajikan dengan konsep penurunan rumus matematika, dan langkah-langkah menyelesaikan soal dengan pengerjaan hitungan dasar matematika serta menyelesaikan soal dengan cara yang lebih sederhana dan praktis dengan catatan mengetahui aturan penggunaan rumus cepat.

adapun langkah-langkah penurunan menyusun rumus cepat persamaan kuadrat baru yang didapat dari bahan belajar (on-line) adalah sebagai berikut :

a. Menentukan jumlah akar-akar persamaan kuadrat awal.

b. Menenukan hasil kali akarakar persamaan kuadrat.

c. Menentukan jumlah akar-akar persamaan kuadrat baru.

d. Menyusun persamaan kuadrat baru.

Dari beberapa uraian di atas dapat disimpulkan bahwa penggunaan rumus cepat persamaan kuadrat dalam penelitian pengembangan ini ialah sisw mengetahui aturan penggunaan rumus cepat serta konsep dasar matematika yang benar dan tidak menyalahi aturan atau konsep matematika, tujuannya adalah siswa mampu berpikir kreatif dalam menyelesaikan soal matematika yang mudah, benar dan praktis..

\section{METODE PENELITIAN}

\section{Jenis Penelitian}

Jenis penelitian yang dilakukan adalah metode penelitian dan pengembangan (Research and Development). Research and Development adalah metode penelitian yang dihasilkan untuk menghasilkan produk tertentu dan menguji keefektifan produk tersebut. Penelitian ini menggunakan penelitian pengembangan Brog and Gall Brog and Gall (1983), yaitu; Suatu proses yang digunakan untuk mengembangkan dan mengesahkan produk bidang pendidikan. Langkahlangkah dalam proses ini pada umumnya dikenal sebagai siklus Research and Development, yang terdiri dari: pengkajian terhadap hasilhasil penelitian sebelumnya yang berkaitan dengan komponenkomponen pada produk yang akan dikembangkan, mengembangkannya menjadi sebuah produk, pengujian pada produk yang telah dirancang, dan peninjauan ulang dan mengoreksi produk tersebut berdasarkan hasil uji coba bahwa temuan dari kegiatan pengembangan yang dilakukan mempunyai obyektivitas.

\section{Target/Subjek Penelitian}

Subjek uji coba di dalam penelitian dan pengembangan ini adalah para ahli yang terdiri atas ahli materi, ahli media, ahli bahasa, guru, serta uji coba kelompok kecil dan uji coba kelompok besar.

\section{Prosedur}

Menurut Brog and Gall yang dikutip oleh Sutopo (2009) di dalam jurnal Ekayana, (2013; 3) 10 tahapan pengembangan Brog and Gall dapat disederhanakan menjadi 7 langkah utama yaitu disesuaikan dengan penelitian yang akan dilakukan. Ketujuh langkah penelitian sesuai yang disarankan oleh Brog and Gall 
yang dikutip dari Ekayana (2013 : 4), $\quad$ yaitu:

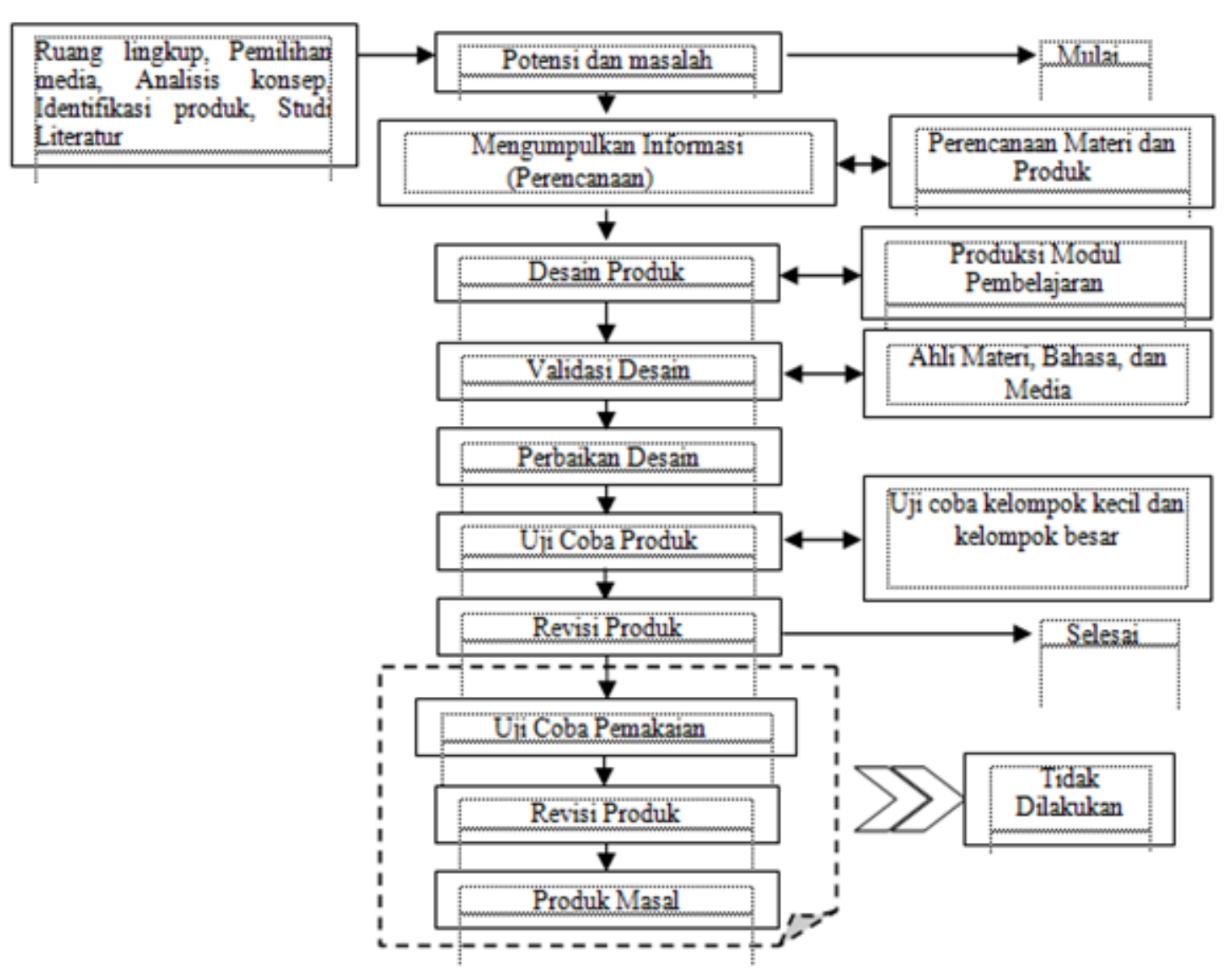

Gambar 1.

Tahapan Pengembangan Penelitian

Intrumen, dan Teknik

\section{Pengumpulan Data}

Instrument yang digunakan untuk memperoleh tanggapan ahli materi, ahli media, ahli bahasa, guru yang ahli dalam bidangnya, uji kelompok kecil dan uji kelompok besar, yaitu berupa angket dan wawancara. Sedangkan untuk melihat efektivitas hasil pengembangan digunakan instrument berupa tes (ujian tulis essay).

\section{Teknik Analisis Data}

Penelitian pengembangan bahan ajar materi persamaan kuadrat berbantuan rumus cepat menggunakan
2 teknis analisis data, yakni kuantitatif dan kualitatif. Data kuantitatif yaitu data yang diolah dengan perumusan angka. Data kuantitatif diperoleh dari skor angket penilaian validator dan penilaian siswa. Sedangkan Data Kualitatif yaitu data yang berupa deskripsi dalam bentuk kalimat. Data kualitatif ini berupa kritik dan saran validator terhadap produk yang dikembangkan dan deskripsi keterlaksanaan uji coba produk. Analisis hasil data berupa angket dan wawancara.

Dikutip dari jurnal Rully anggraini, (2016:72) Rumus 
menghitung skor penilaian total dapat dicari dengan menggunakan rumus sebagai berikut :

$$
\begin{gathered}
\bar{x}=\frac{\sum_{i=1}^{n} x_{i}}{n} \\
\text { Dengan : } \\
x_{i}=\frac{\text { jumlah skor }}{\text { skor maks }} \times 4
\end{gathered}
$$

Keterangan :

$\bar{x}=$ rata-rata akhir

$x_{i}=$ nilai uji operasional angket tiap siswa

$n$ = banyaknya siswa yang mengisi angket
Langkah selanjutnya angket validasi ahli terkait kegrafikan, penyajian, kesesuaian isi, kebahasaan dan kesesuaian modul memiliki 4 pilihan jawaban sesuai konten pertanyaan. Dikutip dari Lucky Chandra, (2013:5) Masing-masing pilihan jawaban memiliki skor berbeda yang mengartikan tingkat validasi modul materi persamaan kuadrat berbantuan rumus cepat. Skor penilaian dari tiap pilihan jawaban dapat dilihat dalam table 2 .

Table 2

\section{Skor Penilaian Validasi Ahli}

\begin{tabular}{|c|c|}
\hline Skor & Pilihan jawaban Kelayakan \\
\hline 4 & Sangat Baik \\
\hline 3 & Baik \\
\hline 2 & Kurang Baik \\
\hline 1 & Tidak Baik \\
\hline
\end{tabular}

Hasil dari skor penilaian dari masing-masing validator ahli media, ahli materi dan ahli bahasa tersebut kemudian dicari rata-ratanya dan dikonversikan ke pernyataan untuk menentukan kevalidan dan kelayakan modul materi persamaan kuadrat berbantuan rumus cepat. Penkonversian skor menjadi pertanyaan penilaian ini dapat dilihat dalam table 3

Tabel 3

Kriteria Validasi Ahli

\begin{tabular}{|c|c|c|}
\hline Skor Kualitas & Kriteria Kelayakan & Keterangan \\
\hline $3,26<\bar{x} \leq 4,00$ & Sangat Layak Digunakan & Tidak Revisi \\
\hline $2,51<\bar{x} \leq 3,26$ & Layak digunakan & Revisi Sebagian \\
\hline $1,76<\bar{x} \leq 2,51$ & Kurang Layak Digunakan & $\begin{array}{c}\text { Revisi Sebagian \& } \\
\text { Pengkajian Ulang Materi }\end{array}$ \\
\hline $1,00<\bar{x} \leq 1,76$ & Tidak Layak Digunakan & Revisi Total \\
\hline
\end{tabular}

Sedangkan menurut Rinaldi indra santoso, (2016:3) angket respon siswa terhadap penggunaan produk memiliki 4 pilihan jawaban sesuai konten pertanyaan. Masing-masing jawaban memiliki skor berbeda yang mengartikan tingkat kesesuaian produk bagi pengguna. Skor penilaian dari tiap pilihan jawaban dapat dilihat dalam tabel 4 
Tabel 4

Skor Penilaian Terhadap Pilihan Jawaban

\begin{tabular}{|c|c|}
\hline Skor & Pilihan jawaban kemenarikan \\
\hline 4 & Sangat Setuju \\
\hline 3 & Setuju \\
\hline 2 & Tidak Setuju \\
\hline 1 & Sangat Kurang Setuju \\
\hline
\end{tabular}

Hasil dari skor penilaian dari masingmasing siswa tersebut kemudian dicari rata-rata dan dikonversikan kepertanyaan untuk menentukan kemenarikan dan kemudahan modul

materi persamaan kuadrat berbantuan rumus cepat. Dikutip dari Ana kurnia sari, (2015:5) penkonversian skor menjadi pertanyaan penilaian ini dapat dilihat dalam table 5 .

Table 5

Kriteria untuk Uji Kemenarikan dan Kemudahan

\begin{tabular}{|c|c|}
\hline Skor Kualitas & $\begin{array}{c}\text { Pertanyaan Kualitas Aspek kemenarikan dan } \\
\text { Kemudahan }\end{array}$ \\
\hline $3,26<\bar{x} \leq 4,00$ & Sangat Menarik / Sangat Mudah Digunakan \\
\hline $2,51<\bar{x} \leq 3,26$ & Menarik / Mudah Digunakan \\
\hline $1,76<\bar{x} \leq 2,51$ & Kurang Menarik / Sulit Digunakan \\
\hline $1,00<\bar{x} \leq 1,76$ & Sangat Kurang Menarik / Sangat Sulit Digunakan \\
\hline
\end{tabular}

HASIL PENELITIAN DAN

\section{PEMBAHASAN}

Berdasarkan

penelitian mengenai pengembangan bahan ajar materi persamaan kuadrat berbantuan rumus cepat yang telah dilakukan, diperoleh hasil penelitian sebagai berikut:

\section{Potensi dan masalah}

Identifikasi masalah pada penelitian ini dilakukan dengan memberikan lembar soal (pre test) dan wawancara dan observasi terhadap beberapa sumber belajar yang di pakai di salah satu SMA Bandar Lampung. Hasil wawancara dan observasi adalah sebagai berikut: (a) Siswa yang dapat mengerjakan soal pre tes rata-rata $14,06 \%$, hal ini karena kurangnya pemahaman konsep menyusun persamaan kuadrat baru serta siswa yang sulit mengatur waktu saat mengerjakan soal. (b) siswa masih mengalami kesulitan dalam memahami konsep dasar matematika serta belum adanya pembahasan soal-soal ujian di dalam buku siswa. Hal ini menyebabkan kurangnya pengetahuan siswa dalam memahami pola-pola soal ujian yang diberikan. (c) Bahan ajar yang dikembangkan adalah materi pada bab persamaan kuadrat kelas $X$ SMA/MA.

\section{Pengembangan produk awal}

Dalam proses pengembangan produk ini, peneliti mengumpulkan informasi berupa 
teori pendukung untuk produk yang akan dibuat. Peneliti mengumpulkan beberapa bahan ajar yang digunakan di sekolah baik berupa silabus pembelajaran matematika SMA/MA, buku paket, buku sekolah elektronik (BSE), buku bank soal ujian nasional dan ujian masuk perguruan tinggi, serta sumbersumber lain yang relevan dengan penelitian.

\section{Desain produk}

Tahap ini merupakan tahap dimana objek bahan ajar dibuat. Pada proses ini, peneliti tidak serta merta merubah isi materi yang ada. Namun peneliti mengutamakan konsep dasar persamaan kuadrat serta menambahkan rumus cepat yang diperoleh dari konsep dasar dan penurunannya. Kemudian modul di desain lebih menarik dengan memperhatikan standar kelayakan isi, standar kelayakan penyajian, dan standar kelayakan kebahasaan. (a) Standar kelayakan isi terdiri dari kesesuaian materi dengan standar kompetensi dan kompetensi dasar, keakuratan materi, kemutakhiran materi, serta mendorong keingintahuan siswa. (b) Kelayakan penyajian bahan ajar, Bahan ajar yang dikembangkan berupa modul matematika materi persamaan kuadrat berbantuan rumus cepat sebagai sumber belajar yang disajikan dengan memperhatikan teknik penyajian yaitu: keruntutan konsep, pembangkit motivasi awal bab, melibatkan peserta didik, ketertautan antar bab/sub bab/alenia serta kesesuaian karakteristik mata pelajaran. Hal ini dapat dilihat pada gambar di bawah ini:
Menggunakan cara normal

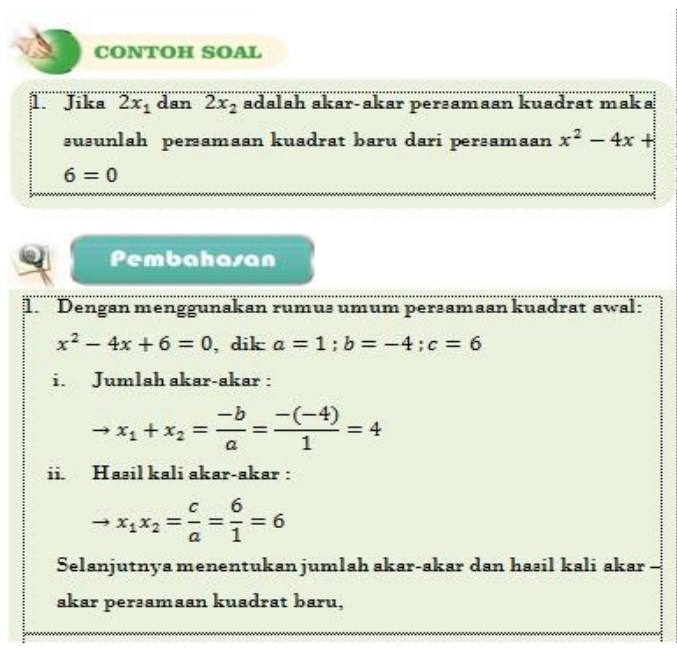

Menggunakan rumus cepat

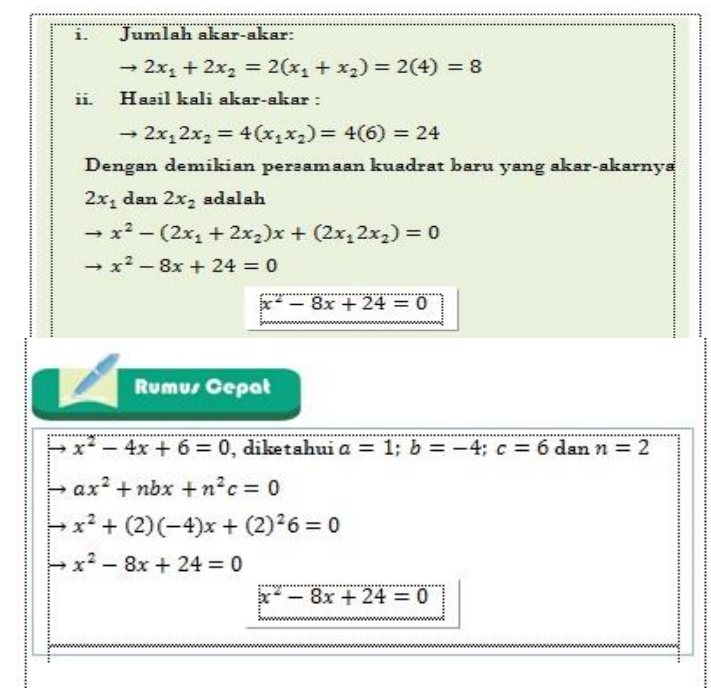

Gambar 2.

Penyelesaian Soal Menggunakan Rumus Cepat

Modul persamaan kuadrat

berbantuan rumus cepat ini

skala space 1,5; font $12 \mathrm{pt}$; dan jenis

menggunakan ukuran kertas b5; huruf Times New Roman (Headings CS), Bodoni MT, Snap IT, Chiller, 
Comic Sans MS, Gill Sans Ultra Bold, Clarendon Bkk BT, Lucida Calligraphy, Adobe Gothic Std B, Bauhaus 93. Modul materi persamaan kuadrat ini terdiri dari 120 lembar, yaitu lampiran depan (cover, kata pengantar, daftar isi, kata kunci, peta konsep dalam bentuk mindmap), kemudian untuk isi modul terdiri dari empat kegiatan belajar yang tiap kegiatan belajarnya terdiri dari (materi, contoh soal, rangkuman, latihan, tes formatif dan refleksi), di akhir kegiatan mempunyai pembahasan soal-soal ujian baik ujian nasional dan ujian masuk perguruan tinggi (SBMPTN dan UM-PTAIN), serta lampiran belakang (kunci jawaban, glosarium, indeks, dan daftar pustaka). (c) Standar kelayakan kebahasaan terdiri dari ketetapan struktur kalimat, keefektifan kalimat, dan kebakuan istilah. Keteptan struktur kalimat merupakan kalimat yang dipakai mewakili isi pesan dan informasi yang ingin disampaikan dengan tetap mengikuti tata kalimat bahasa Indonesia. Keefektifan kalimat merupakan kalimat yang dipakai sederhana dan langsung kesasaran. Serta kebakuan istilah merupakan istilah yang digunakan sesuai kamus besar bahasa Indonesia dan istilah teknis yang telah baku digunakan dalam TIK. Padanan istilah teknis yang masih cukup asing diberi penjelasan pada glosarium.

\section{Validasi Desain}

Validasi desain pengembangan modul materi persamaan kuadrat berbantuan rumus cepat di uji oleh 7 ahli, yang terdiri dari 3 ahli materi, 2 ahli media, dan 2 ahli bahasa. Kriteria dalam penentuan subyek ahli, yaitu: (1) Berpengalaman di bidangnya, (2) Berpendidikan minimal S2 atau sedang menempuh pendidikan S2. Validasi juga dilakukan oleh 2 praktisi yaitu guru Matematika dan guru Bahasa SMA/Ma, dengan kriteria sebagai subyek praktisi adalah: (1) Berpengalaman dibidangnya, Berpendidikan minimal S1, (3) Merupakan guru Matematika dan guru Bahasa di salah satu SMA Bandar lampung. Instrumen validasi menggunakan skala Likert. Adapun hasil validasi ahli dan validasi praktisi tahap 2 sebagai berikut berikut.

Uji Kelayakan Bahan Ajar

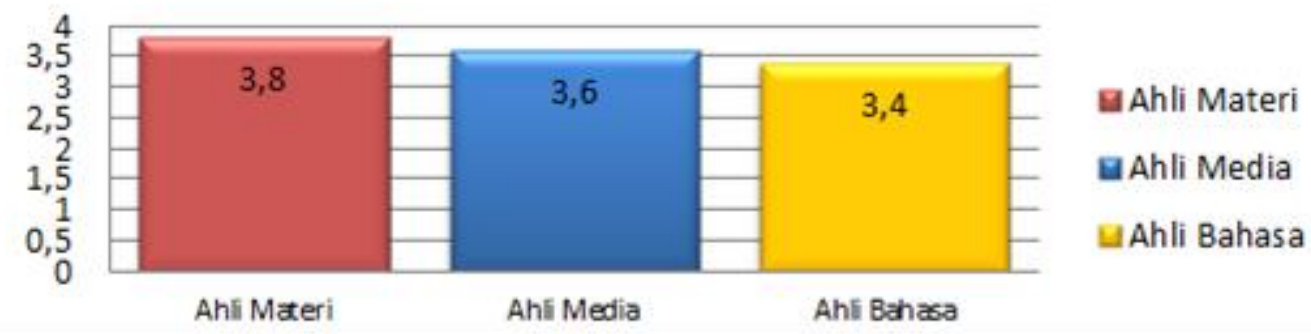

Gambar.3

Grafik Kelayakan Bahan Ajar 


\section{Revisi Desain}

Setelah desain produk divalidasi melalui penilaian ahli materi, ahli media, dan ahli bahasa serta guru Matematika SMA/MA Kelas X, peneliti melakukan revisi terhadap desain produk yang dikembangkan berdasarkan masukan-masukan ahli tersebut. Pada kelayakan penyajian belum adanya glosarium maka ahli materi menyarankan untuk menamahkan glosarium, serta ahli materi menyarankan setiap rumus tambahkan deskripsi penurunan rumus. Ahli media menyarankan modul sesuaikan dengan standar ISO serta sesuaikan pola dan tata letak yang ditampilkan agar modul terlihat lebih konsisten dan tidak terlalu rapat. Sedangkan ahli bahasa menyarankan kalimat didalam modul harus sesuai dan efektif agar siswa dapat dengan mudah menerima informasi yang terdapat didalam bahan ajar tersebut.

\section{Uji Coba Produk}

Sebelum diuji coba ke kelompok besar, produk diuji cobaka ke kelompok kecil yang dilakukan dengan memilih secara acak sebanyak 15 siswa-siswi di salah satu SMA Bandar Lampung. Selanjutnya produk di ujicobakan di kelompok besar sebanyak 34 siswasiswi di salah satu SMA Bandar lampung. Hal ini sesuai dengan pernyataan Arief S. Sadiman, (2012:184-185) bahwa uji coba kelompok kecil dapat dilakukan pada 10-15 siswa yang dapat diwakili populasi target, uji kelompok besar sekiar 30-40 lebih siswa dengan berbagai karakteristik, sesuai dengan karakteristik populisasi sasaran. Adapun hasil perbandingan uji coba kelompok kecil dan besar sebagai berikut.

\section{Uji kelompok kecil dan kelompok besar}

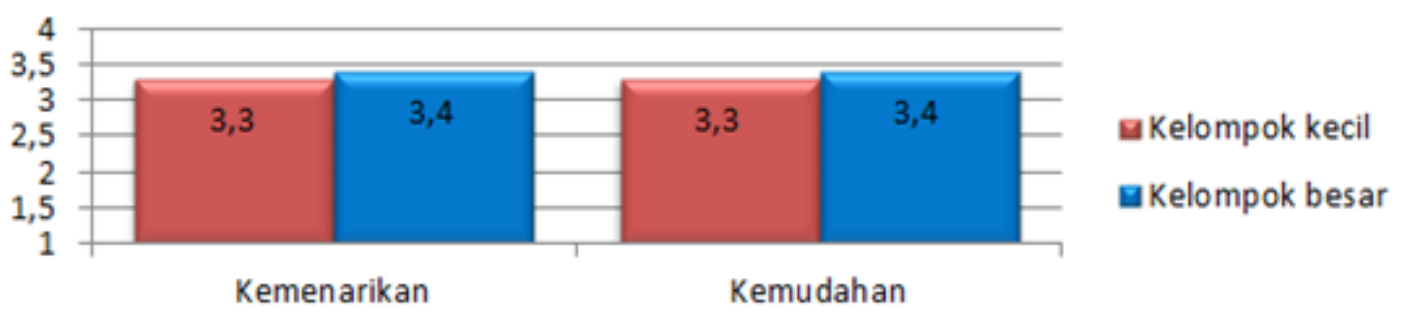

\section{Gambar 4.}

\section{Uji kelompok keci dan Kelompok besar}

\section{KESIMPULAN DAN SARAN}

\section{Kesimpulan}

Berdasarkan hasil penelitian pengembangan dapat disimpulkan bahwa pengembangan bahan ajar materi persamaan kuadrat berbantuan rumus cepat layak, menarik, dan bagi siswa.
Pengembangan bahan ajar berupa modul telah divalidasi oleh ahli materi, ahli media dan ahli bahasa dengan memperoleh kriteria sangat Layak. Selanjutnya diuji kemenarikan dan kemudahan bahan ajar yang diujicobakan pada keompok kecil dan kelompok besar, 
pada uji kemenarikan dan kemudahan memperoleh kriteria sangat menarik dan sangat.

\section{Saran}

Berdasarkan hasil penelitian, analisis, pembahasaan, dan kesimpulan dapat dikemukakan beberapa saran sebagai berikut: (1) Bagi guru tidak serta merta memberikan rumus cepat di awal proses pembelajaran melainkan rumus cepat dapat di berikan di akhir pembelajaran setelah siswa mengetahui konsep dasar persamaan kuadrat. (2) Bagi siswa bahan ajar materi persamaan kuadrat berbantuan rumus cepat dapat dimanfaatkan untuk menyelesaikan soal dengan cara yang lebih praktis dan sederhana. (3) Bagi peneliti dalam pembuatan modul materi persamaan kuadrat berbantuan rumus cepat terdapat beberapa kendala atau kesulitan yang mungkin bisa menjadi perbaikan bagi peneliti yang lain untuk mengembangkan bahan ajar berbantuan rumus cepat, diantaranya: Pertama Pengembangan rumus cepat persamaan kuadrat ini dapat dikembangkan lagi oleh peneliti selanjutnya dengan menerapkan pada soal berbasis problem solving, Kedua bahan ajar ini mempunyai deskripsi penurunan rumus cepat yang menarik sehingga peneliti selanjutnya dapat mengembangkan rumus cepat sesuai dengan konsep dasar matematika dan tidak diperbolehkan bagi peneliti lain yang akan mengembangkan rumus cepat tanpa deskripsi konsep dasar matematika.

\section{DAFTAR PUSTAKA}

Angraini, R. (2016). 'Pengembangan Bahan Ajar Materi Trigonometri Berbantuan Software iMindMap di SMAN 2 Negeri Katon Pesawaran pada Semester II.' Skripsi : IAIN Raden Intan Lampung, Bandar Lampung.

Arikunto, S. (2013). Prosedur Penelitian Suatu Pendekatan Praktik, Jakarta: Rineka Cipta.

Brog and Gall. 1983. 'Education research: An Introduction, Longman Edisi 2,' McKayUniversity of Wisconsin-Madison, New York. dikutip dari Nicha, YV, (2016) Pengembangan Lembar Kerja Siswa (LKS) Berbasis Inkuiri Terbimbing pada Materi Teorema Phythagoras' Skripsi :IAIN Raden Intan Lampung, Bandar Lampung, , h.42.

Chandra, L. (2014) 'pengembangan lembar kerja siswa (LKS) Fisika materi tekanan mencangkup ranah kognitif, afektif dan psikomotor sesuai kurikulum 2013 untuk siswa SMP/MTs' Jurnal malang: Universitas Islam Negeri, h.6.

Daryanto \& Cahyo, AD. (2014). Pengembangan Perangkat Pembelajaran (Silabus, Rpp, Phb, Bahan Ajar), Yogyakarta: Gava Media.

Ekayana, AG. (2013). 'Pengembangan

Perangkat Pembelajaran 
Mikrokontroler Berbasis Advance Virtual Risc (AVR) dalam Mata Pelajaran Teknik Mikrokontroler'. E-jurnal Program Pascasarjana Universitas Pendidikan Ganesha, (Jurnal :Universitas Pendidikan Ganesha) Vol. 3, h.4.

Kurnia, AS, Ertikanto, C, \& Suana, W. (2015). 'Pengembangan LKS Memanfaatkan Laboratorium Virtual pada Materi Optik Fisis dengan Pendekatan Saintifik,' Jurnal Fisika : Universitas Lampung, Vol.3, No. 2, h.5.

Prastowo, A. (2014). Pengembangan Bahan Ajar Tematik Tinjauan
Teoritis dan Praktik. Jakarta: Kencana.

Sadiman, A. (2012). Media Pendidikan, Pengertian, Pengembangan, dan Pemanfaatannya, Jakarta : Raja Persada.

Santoso, R. Ciptono, \& Triatmanto, (2016). 'Pengembangan Modul Berbasis WEB Materi Protozoa Biologi.' Jurnal : Universitas Negeri Yogyakarta Vol. 5, No. 4, h.3.

Setiyono, A. (2005). Mathmagic Cara Jenius Belajar Matematika, Jakarta : Kompas Gramedia.

Tim Penyusun, (2013). UndangUndang Sisdiknas Nomor 20 Tahun 2003, Jakarta : Sinar Grafika. 
